\title{
Growth Region Impacts Cell Wall Properties and Hard-to-Cook Phenotype of Canned Navy Beans (Phaseolus vulgaris)
}

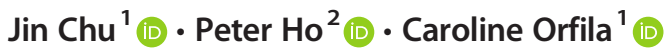

Received: 28 October 2019 / Accepted: 30 March 2020 / Published online: 18 April 2020

(C) The Author(s) 2020

\begin{abstract}
Cellular mechanisms underpinning the hard-to-cook phenomenon are poorly understood. Navy beans (Phaseolus vulgaris) from the same cultivar but grown in different regions of North America showed different canning characteristics. Up to $46.4 \%$ more force was required to disrupt hard beans (HB) grown in Ontario compared with soft beans (SB) grown in Manitoba. HB absorbed $12.5 \%$ and $14.7 \%$ less water during blanching and canning, respectively. Microscopic assessment revealed that canning led to swelling of middle lamella and cell walls, but preservation of cell adhesion in both types of beans. Immunofluorescence microscopy showed reduced labelling of methyl-esterified homogalacturonan (HG) and more non-methyl-esterified HG and arabinan epitopes in HB. Compositional analysis indicated that the polysaccharides from HB were less water soluble and enriched in neutral sugars, including $46.5 \%$ more arabinose and 51.8\% more galactose than in SB. ELISA analysis of polymers in the canning medium supported the increased solubility of cell wall polymers in SB. In the same cultivar, growth region affects cell wall properties with consequences for processing, eating and nutritional quality.
\end{abstract}

Keywords Bean $\cdot$ Hard-to-cook $\cdot$ Cell wall polysaccharide $\cdot$ Cell adhesion $\cdot$ Growth region $\cdot$ Pectin

\section{Introduction}

Navy beans (Phaseolus vulgaris) canned in tomato sauce are a popular product consumed around the world. It is the most popular legume product in the UK as $50 \%$ of the UK population consumes around $300 \mathrm{~g}$ per week, higher than any other cooked vegetable source including peas and carrots (Henderson et al. 2002). Canning quality is associated with high water absorption necessary for starch gelatinisation, softening and retention of bean structure. Industry evaluation for the canning quality usually includes hydration coefficient, visual appearance and most importantly hardness and texture (Mendoza et al. 2014). Hard-to-cook (HTC) defects manifest in a reduction of water absorption and solute exchange with the canning medium leading to hard beans and a thin sauce, attributes rejected by consumers. HTC can be overcome by

Caroline Orfila

c.orfila@leeds.ac.uk

1 Nutritional Sciences and Epidemiology, School of Food Science and Nutrition, University of Leeds, Leeds LS2 9JT, UK

2 Food Colloids and Bioprocessing Group, School of Food Science and Nutrition, University of Leeds, Leeds LS2 9JT, UK increasing cooking time, increasing energy utilisation in the process. Several non-invasive processes have been designed to identify HTC beans from processing line, including visible and near-infrared spectroscopy (Mendoza et al. 2014) and automated visual inspection (Erkinbaev et al. 2017).

The HTC phenomenon has been widely studied, but up to now, there is no clear mechanism proposed to explain its development (Cuauhtémoc et al. 1993; Hentges et al. 1991; Liu 1995; Pirhayati et al. 2011). HTC is widely associated with poor postharvest and storage conditions such as high temperature and humidity (Sefa-Dedeh et al. 1979) and may also be due to differences between varieties (Bernal-Lugo et al. 1997) and growth conditions. Beans are sourced from many different regions around the world, including North America, China and East Africa. Variability poses quality problems for processors, which have to adapt their processing conditions (cooking time) to obtain optimal final products. Climate change is adding additional challenges in crop production (Challinor et al. 2007). Most studies have focused on the effect of growing conditions on yield. Understanding how growing conditions affect quality may be useful to breeders and processors.

The cell wall has been suggested to play an important role in hard-to-cook defects. Liu (1995) suggested the direct involvement of cell wall pectin and storage protein, both of 
which are sensitive to $\mathrm{pH}$ and/or ion composition, while Hohlberg and Stanley suggested a role for protein and starch (Hohlberg and Stanley 1987). Shomer et al. described the changes to cell wall and middle lamella ultrastructure during cooking of normal and HTC beans (Shomer et al. 1990). HTC beans appeared to retain the integrity of the middle lamella during cooking leading to maintenance of strong cell adhesion. The differences in middle lamella integrity did not explain the reduction in water absorption. Bernal-Lugo et al. (1997) suggested that reduced solubility of pectic polysaccharides is more important in determining cooking time than cytoplasmic starch gelatinisation or protein denaturation (Bernal-Lugo et al. 1997). Shiga et al. (2004) showed that the texture of beans was associated with the solubility of cell wall polysaccharides; harder beans showed reduced solubility compared with softer beans (Shiga et al. 2004). The amount of soluble pectin in various beans was associated with the firmness of cooked beans (Wang and Chang 1988). Lu and Chang (1996) also indicated that larger amount of soluble pectin decreased the firmness of the navy beans (Lu and Chang 1996).

The solubilisation and depolymerisation of polymers were found to be responsible for tissue softening of plant tissue during cooking (Brett and Waldron 1996; Liu 1995). Heat treatment influences the structure of the cell wall, causing partial disassembly of the cell wall and middle lamella (Stolle-Smits et al. 1998). More specifically, the solubilisation of pectic polysaccharides is associated with cell separation (Ilker and Szczesniak 1990; Rocha et al. 2000).

Homogalacturonan (HG) is the most abundant pectic polysaccharide comprising approximately 60 to $65 \%$ of the pectin in bean cell walls (Caffall and Mohnen 2009; Mohnen 2008). HG can be de-esterified by pectin methylesterases (PMEs) (Clausen et al. 2003) and become an un-methyl-esterified HG in the cell wall. The un-methyl-esterified HG can form calcium cross-links and bring blocks of un-methyl-esterified HG chains into tightly packed conformations, consequently contributing to wall strength (Caffall and Mohnen 2009; Stolle-Smits et al. 2000). Stolle-Smits et al. (1999) studied the bean pod and indicated that the increase in HG-calcium complexes in the wall increases cell wall stiffening and declines the wall expansibility. (Stolle-Smits et al. 1999). HGcalcium complexes can result in gel formation and contribute to cell wall strength, cell intercellular adhesion and stomatal function (Caffall and Mohnen 2009; Willats et al. 2001). Neutral sugars in rhamnogalacturonan (RGI) side chains were also found to influence cell adhesion (Caffall and Mohnen 2009). Stolle-Smits et al. (1999) claimed that in bean pod, a decrease in RGI neutral sugar side chains was associated with an increase in wall stiffening and decline in wall expansibility. The degradation of arabinan and galactan coincided with the de-methylation of HG by PME; therefore, it is difficult to know what the most important factor is contributing to cell wall strength. Navy beans (Phaseolus vulgaris) were found to contain high amounts of arabinan and medium amount of galactan (Shiga et al. 2004). Therefore, it is likely that both HG and RGI content may contribute to the texture characteristic of the beans.

Monoclonal antibodies are powerful tools for targeting a small fraction of molecules against a complex background (Manfield et al. 2005). Several studies have used monoclonal antibodies to localise the pectin epitopes at the level of individual cell wall, in order to visualise the microstructure of the cell wall, and their spatial changes during plant development. This approach had successfully been used to study the role of pectins as determinants of texture in tomato, pea root and pea cotyledon (Knox 1997; McCartney et al. 2000; Ordaz-Ortiz et al. 2009; Orfila et al. 2001). In this study, three anti-pectin probes (JIM5, JIM7 and LM5) were used to explore the cellular mechanisms underpinning tissue hardness in navy beans. JIM5 binds in preference to HG with a relatively low level of methyl-esterification or fully un-esterified HG (Willats et al. 2000). JIM7 binds to a range of HG epitopes with a relatively high level of methyl-esterification, but not completely de-esterified HG (Willats et al. 2000). And LM6 binds to arabinan, which is the side chain of RGI (McCartney and Knox 2002).

The aim of the study was to compare the physical and cellular properties of navy beans from a single commercial cultivar that had been grown in similar commercial farming regimes but in two different geographical locations of North America. A batch of beans were grown in the Central Region of Manitoba characterised by short, highly humid and hot (up to $\left.53^{\circ} \mathrm{C}\right)$ summers with long, extremely cold $\left(-40^{\circ} \mathrm{C}\right)$ winters, while another batch were grown in the adjacent region of Ontario with humid continental climate characterised by longer warm $\left(28^{\circ} \mathrm{C}\right)$, humid summers and shorter milder winters $\left(-5^{\circ} \mathrm{C}\right)$. The beans are commercially grown with optimal soil and agronomical conditions to optimise yield. However, the beans provide a unique opportunity for a natural experiment to investigate the impact of the agri-climatic environment on the HTC phenotype. We investigated the mechanical properties of the beans after commercial blanching and canning. We analysed the cell wall structural properties using polymerspecific probes to localise cellulose and pectin polysaccharides in the blanched and cooked bean and analysed the solubility and composition of cell wall polymers in the canning medium. We hypothesise that HTC beans will have lower solubility of pectic polysaccharides.

\section{Material and Methods}

\section{Plant Material}

Commercial beans from the same cultivar but grown in different geographical regions in North America were studied. A batch of beans were grown in the Central Region of Manitoba 
characterised by short, highly humid and hot (up to $53{ }^{\circ} \mathrm{C}$ ) summers with long, extremely cold $\left(-40^{\circ} \mathrm{C}\right)$ winters, while another batch were grown in the adjacent region of Ontario with humid continental climate characterised by longer warm $\left(28^{\circ} \mathrm{C}\right)$, humid summers and shorter milder winters $\left(-5^{\circ} \mathrm{C}\right)$. The beans are commercially grown with optimal soil and agronomical conditions to optimise yield. Beans were harvested in July to September, stored in outdoor silos between October and February and then shipped to the UK for industrial canning in March. Beans from both batches were processed in identical conditions, first blanched for $20 \mathrm{~min}$ at $85^{\circ} \mathrm{C}$, followed by sterilisation in a rotary reel and spiral retort simulator for $7 \mathrm{~min}$ at $126^{\circ} \mathrm{C}$ and $14 \mathrm{~min}$ at $128^{\circ} \mathrm{C}$ in tomato sauce. Hard beans (labelled as HB) were grown in Ontario, and soft beans (labelled as SB) were grown in Manitoba. The canned bean samples were analysed after being drained and washed with tap water.

\section{Mechanical Properties of Blanched and Canned Beans}

Beans' firmness was analysed using TA.XT plus texture analyser instrument with a $50 \mathrm{~kg}$ load capacity. Three probes were used: 2-mm diameter cylinder probe was used to assess the firmness of single bean skin; 20-mm diameter cylinder probe was used to assess the firmness of single half bean cotyledon; and compression of single beans (skin or cotyledon) was a rate of $1 \mathrm{~mm}^{*} \mathrm{~s}^{-1}$ to a maximum puncture distance of $3.5 \mathrm{~mm}$. All the experiments were done with 10 replicates for each type of bean. A miniature Kramer shear cell was used to assess the firmness of a whole batch of canned beans $(10 \mathrm{~g})$. $10 \mathrm{~g}$ of canned beans without sauce was placed into the dualuse slotted base and extruded with the miniature Kramer shear cell. A return to start option was set, with a $2 \mathrm{~mm}^{*} \mathrm{~s}^{-1}$ test speed to a maximum extrusion distance of $40 \mathrm{~mm}$.

\section{Cytochemical and Immunofluorescence Microscopy}

Skin and cotyledon samples were cut into $0.5 \mathrm{~cm}^{3}$ cubes using a scalpel. Samples were immediately prepared for microscopy as described in Orfila et al. (2001). Sections obtained from the wax-embedded material were incubated with a solution of $25 \mathrm{mg} / \mathrm{ml}$ calcofluor white (Fluorescent Brightener 28, Sigma, UK) in $\mathrm{dH}_{2} \mathrm{O}$ for $30 \mathrm{~s}$ at RT. Then, sections were washed under gentle stream of tap water and mounted with PBS containing Citifluor AF3 and covered with a glass coverslip, and sections were observed using a fluorescence microscope fitted with an UV filter (Olympus BH-2).

Prior to immunolabelling, sections obtained from the waxembedded material were incubated in toluidine blue $(0.01 \%$ $\mathrm{w} / \mathrm{v}$ toluidine blue $\mathrm{O}$ in PBS) for $10 \mathrm{~min}$ to reduce autofluorescence. Toluidine blue was washed out under a gentle stream of tap water. The sections then were incubated in 3\% bovine serum albumin in phosphate-buffered saline (BSA-
PBS) for $1 \mathrm{~h}$. Sections to be labelled with rat monoclonal antibodies were incubated for $1 \mathrm{~h}$ in a solution containing the primary antibody (which in this study were JIM5, JIM7 and LM6) diluted 1:10 in BSA-PBS. The sections were then washed under a gentle stream of tap water and subsequently incubated for $1 \mathrm{~h}$ in a solution containing goat anti-rat $\operatorname{IgG}$ linked to fluorescein isothiocyanate (FITC; Sigma, UK) diluted 1:100 in BSA-PBS. Then, the sections were washed under a gentle stream of tap water and mounted with a glass cover glass slip in PBS containing Citifluor AF3 which is a PBS/ glycerol-based anti-fade solution. Sections were viewed with a microscope (Olympus BH-2) equipped with epifluorescence. In the control experiment, the primary antibody was omitted.

\section{Determination of Total Dietary Fibre by the AOAC Method (991.43)}

Canned beans samples were analysed for total dietary fibre, water-insoluble polysaccharides (WIP) and water-soluble polysaccharides (WSP), following an Association of Organic Analytical Chemists (AOAC) (Cunniff and Horwitz 2000) official method (991.43) using the total dietary fibre assay kit (Megazyme, Bray, Ireland) with minor modifications (Aldwairji et al. 2014; Chu et al. 2017). It was determined in triplicates with a starting sample weight of $5 \mathrm{~g}$ (wet weight).

Beans were homogenised and dissolved in $100 \mathrm{ml}$ MES/ TRIS buffer (molarity, $\mathrm{pH}-8.2$ ) at room temperature. Enzyme digestion was performed by incubating the samples with $150 \mathrm{IU}$ of heat-stable $\alpha$-amylase in shaking water bath at $100{ }^{\circ} \mathrm{C}$ for $35 \mathrm{~min}$. This was followed by incubation with $35 \mathrm{IU}$ of protease for $30 \mathrm{~min}$ in shaking water bath at $60{ }^{\circ} \mathrm{C}$. Then, the $\mathrm{pH}$ was adjusted to 4.5 , and the sample was incubated at $60{ }^{\circ} \mathrm{C}$ with $640 \mathrm{IU}$ amyloglucosidase for $30 \mathrm{~min}$ in shaking water bath for further starch digestion. Then, the digested mixture was precipitated with four volumes of $95 \%$ ethanol which had been preheated to $60{ }^{\circ} \mathrm{C}$. The mixture was filtered through 3 layers of miracloth. This is a modification from the original protocol, replacing the sintered glass filter by 3 layers of miracloth filter. This mode of filtration was found to ease the recovery of the fibre residue without compromising yields (Aldwairji et al. 2014). The residual was washed with ethanol and acetone and then dried in an oven at $103{ }^{\circ} \mathrm{C}$ until constant weight was achieved. This residue was named waterinsoluble polysaccharides (WIP). The supernatant was precipitated with four volumes of $95 \%$ ethanol and filtered through 3 layers of miracloth. The residual obtained from this step was washed with ethanol and acetone and then dried in an oven at $103{ }^{\circ} \mathrm{C}$ until constant weight was achieved. This residue was named water-soluble polysaccharides (WSP). The supernatant obtained from WSP contained the glucose which was derived from starch. 
Determination of Monosaccharides Using HPAEC-PAD

Cell wall monosaccharide was determined by HPAEC-PAD of hydrolysed material. A PA20 column (Dionex, USA) was used at a flow rate of $0.5 \mathrm{ml} / \mathrm{min}$. The column was washed with $200 \mathrm{mM} \mathrm{NaOH}$ for $10 \mathrm{~min}$ before the injection of each sample and then equilibrated with $10 \mathrm{mM} \mathrm{NaOH}$ for $10 \mathrm{~min}$.

The elution programme consisted of an isocratic elution with $10 \mathrm{mM} \mathrm{NaOH}$ from 0 to $37 \mathrm{~min}$, followed by a linear gradient up to $800 \mathrm{mM} \mathrm{NaOH}$ from 37 to $43 \mathrm{~min}$, and finally down to $10 \mathrm{mM} \mathrm{NaOH}$ from 43 to $45 \mathrm{~min}$. Monosaccharide standards included L-Fuc, L-Rha, L-Ara, D-Gal, D-Glc, D-Xyl, D-Man, D-GalUA and D-GlcA (Sigma, UK); the standard mixture concentration ranges from $0.001 \mu \mathrm{g} / 10 \mu \mathrm{l}$ to $0.1 \mu \mathrm{g} / 10 \mu \mathrm{l}$. A standard mixture run was performed before analysis of a batch of samples for verification of the response factors.

\section{Analysis of Extracted Polymers in Canning Medium Using Antibody Techniques}

\section{Extraction of Polymers}

The canning medium was centrifuged using a BeckmanCoulter J2 centrifuge using 250-ml Beckman tubes at $3840 \mathrm{~g}$ for $30 \mathrm{~min}$ at $20^{\circ} \mathrm{C}$. The supernatant was collected to analyse the extracted polymers from canned beans.

\section{Enzyme-Linked Immunosorbent Assay (ELISA)}

The extracted polymers were determined using ELISA method. The test samples were diluted in $50 \mathrm{mM}$ sodium carbonate to $\mathrm{pH}$ 9.6. Antigen solution, for example, the recovered canning medium, $(200 \mu \mathrm{l})$ was added to appropriate wells of a sorbent microtitre plate (Thermo Nunc ${ }^{\mathrm{TM}}$ MicroWell ${ }^{\mathrm{TM}}$ 96Well Microplates) and incubated overnight at $4{ }^{\circ} \mathrm{C}$. Solutions containing antigen were removed. All binding sites on the plate were blocked with $3 \%(\mathrm{w} / \mathrm{v})$ BSA-PBS buffer ( $200 \mu \mathrm{l} /$ well) for $2 \mathrm{~h}$ at room temperature. Plates were washed with PBS containing $0.05 \%$ Tween (PBS-T) three times. Then, to each well was added $100 \mu \mathrm{l} /$ well of the primary antibody (which in this study were JIM5, JIM7 and LM6) diluted 1:10 in BSA-PBS for $1.5 \mathrm{~h}$. Then, the plates were washed with PSBT six times. To the wells were then added $100 \mu \mathrm{l} /$ well of the secondary antibody (anti-rat lgG coupled to horseradish peroxidise (HRP)) diluted 1:1000 in BSA-PBS and incubated for $1.5 \mathrm{~h}$. Then, the plates were washed with PBST six times. Then, $150 \mu \mathrm{l} /$ well of HRP substrates (3,3',5,5'-tetramethylbenzidine) was added to each well, and plates were incubated for 8-10 min. At last, colour development was stopped by the addition of $35 \mu \mathrm{l} /$ well of $4 \mathrm{M} \mathrm{H}_{2} \mathrm{SO}_{4}$. Absorbance was determined at $450 \mathrm{~nm}$ in a spectroscopic microplate reader (Thermo Multiskan FC). For the control sample, the primary antibody was omitted. Three replicates were applied for individual samples.

\section{Results and Discussion}

\section{Mechanical Properties of Blanched and Canned Beans}

Bean samples from the same cultivar but grown in two different regions of North America (Manitoba and Ontario) were analysed for their mechanical properties after blanching and canning using a texture analyser (TA). After blanching, there was no significant difference in cotyledon hardness (measured as compression to break in single bean samples) between samples (Fig. 1A). However, skin tissue was $22.4 \%$ harder in beans grown in Ontario (referred from now on as hard beans (HB)) compared with beans grown in Manitoba (referred from now on as soft beans (SB)). Furthermore, HB absorbed $12.5 \%$ less water during blanching (Fig. 1D). These results indicate that growing conditions have an effect on the skin properties that may modulate water absorption.

After canning, skin tissue was $22.2 \%$ harder in HB compared with SB, while cotyledon was $48.9 \%$ harder (Fig. 1B). The results for cotyledon were even more pronounced when hardness was analysed using a $10 \mathrm{~g}$ batch of beans using the Kramer TA shear cell which considers extrusion, compression and shearing (Bourne 2002). Using this approach, HB were $86.9 \%$ harder than SB (Fig. 1C). The water-binding capacity of HB was $14.7 \%$ lower (Fig. 1E), while drained weight was $9.1 \%$ lower than in SB (Fig. 1F). This indicates that growing conditions can influence the HTC phenotype, and the differences may be associated with lower hydration.

Using single kernel characterisation technique (SKCS), Erkinbaev et al. (2017) found a positive correlation between moisture content and hardness of dry mung beans. However, their study did not evaluate the hydration or hardness of cooked beans. The hydration rate of food could be an important parameter to consider. However, we could not measure the evolution of hydration or dynamic changes in texture during canning, as has been done previously in carrots (RoccaPoliméni and Flick 2019), due to the hardness of the beans that does not easily allow sensors to be inserted into the beans. Thermal processing dramatically softened the beans; however, neither SB nor HB beans lost their coherence during thermal processing, suggesting strong cell adhesion. In order to explore whether cell wall structure or composition has a role in the HTC phenotype, we compared the microstructure of the HB and SB beans using immunofluorescence microscopy.

\section{Microstructure of Canned Beans}

The microstructure of HB and SB was visualised by cytochemical and immunofluorescence microscopy (Figs. 2 and 3). 
Fig. 1 The physical and mechanical properties of $\mathrm{HB}$ and SB beans. Skin and cotyledon firmness of (A) single blanched bean and (B) single canned bean; (C) Kramer firmness of a whole batch (10 g) of canned beans; water absorption during (D) blanching and (E) canning; (F) drained weight of canned baked beans (sauce been washed).

Values show mean of 10 replicates for (A), (B), (D), and (E) and 3 replicates for $(\mathrm{C})(\mathrm{F})$. Different superscript letters show values that are significantly different at 95\% confidence level
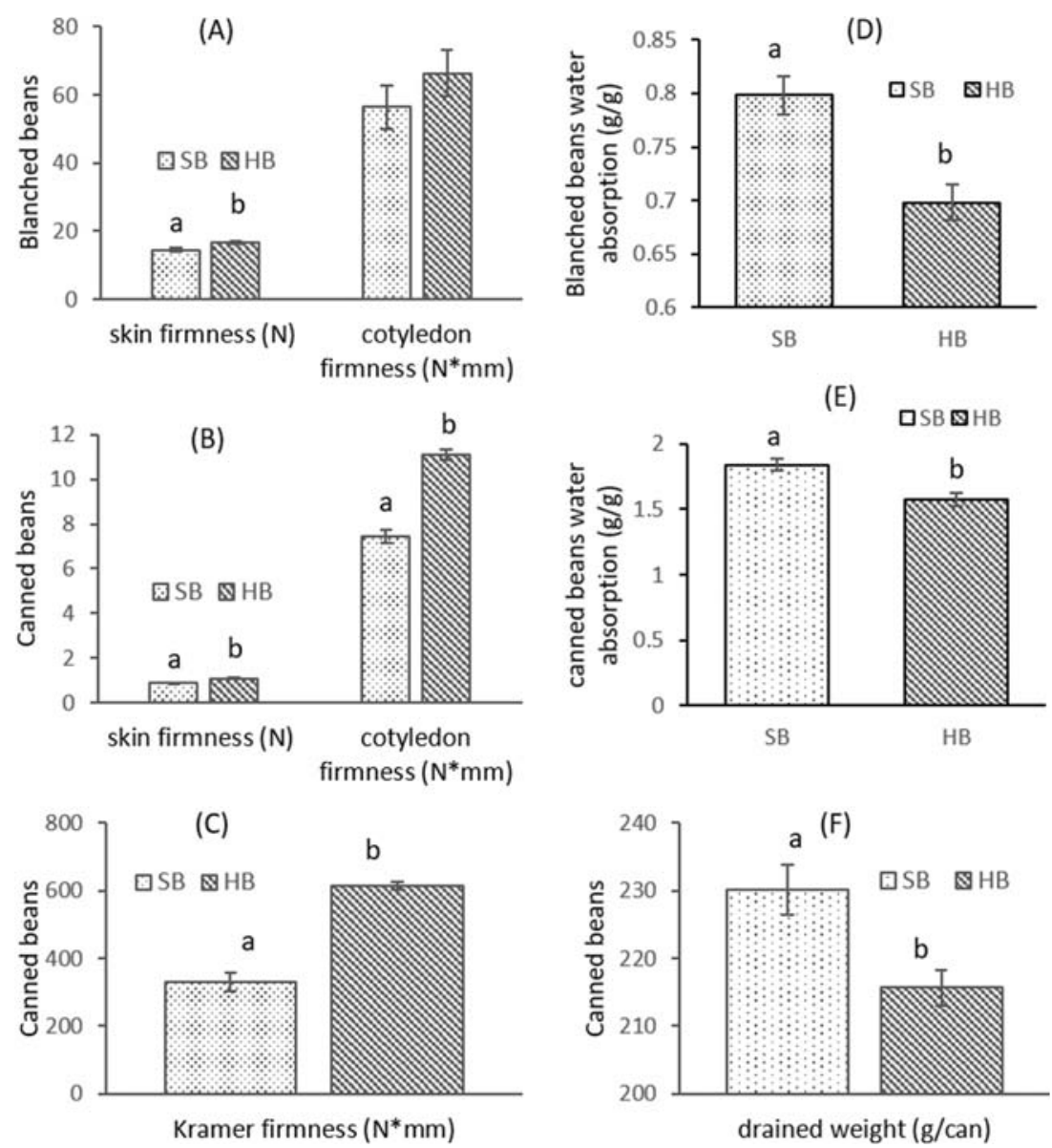

Canning led to loss of skin tissue and swelling of middle lamella and cell walls in cotyledons in both types of beans (Fig. 2). Despite the swelling, cell adhesion was mostly preserved in both types of beans, although the micrographs revealed larger spaces between cells in SB, indicating some cell separation.

Immunofluorescence labelling revealed differences in the pattern of antibody binding between $\mathrm{HB}$ and SB (Fig. 3). HB showed slightly stronger labelling with JIM5 which binds to un-esterified HG, particularly at cell corners. HB also showed stronger labelling with LM6 which binds to pectic arabinan. The most striking difference was in JIM7 labelling which binds to methyl-esterified HG, with SB showing much stronger fluorescence. The differences in HG epitopes could be due to differences in pectin methyl esterase (PME) activity. PME has been shown to be active in fresh and stored navy beans (Mafuleka et al. 1991), although its precise role in bean hardening is not yet clear. It is possible that PME activity is responsible for the de-methyl esterification of pectin in HB during bean maturation, resulting in mechanically stronger cell walls and stronger cell adhesion during hydrothermal processing. The main purpose of blanching is inactivation of enzymes, including PME. Conventional processing still uses soaking at room temperature instead of blanching. Soaking could activate PME and potentially increase bean hardness.

Cell adhesion is largely attributed to the properties of pectin, most particularly calcium cross-linked HG (Jarvis et al. 2003; Mohnen 2008; Orfila 2001; Orfila et al. 2001). Furthermore, our results support a role for arabinans in bean cell adhesion and texture. As shown in Fig. 3, SB had less LM6 binding at the inner walls, as well as poorly shaped cells compare with $\mathrm{HB}$ which had more intact cells and stronger LM6 binding to both inner and outer walls compare with SB. The function of arabinan in the plant cell wall is still poorly understood. NMR studies suggest it to be a very flexible polysaccharide (Renard and Jarvis 1999), and it has been found in many seed cell walls (Dourado et al. 2004) including legume seeds (Gooneratne et al. 1994). Some studies have suggested that the side chains of RGI may contribute to cell adhesion and cell wall strength (Caffall and Mohnen 2009; McCartney et al. 2000; Orfila and Knox 2000). Zdunek et al. (2014) also suggest that more branched pectins were associated with higher firmness texture in pear fruit tissue. Cell wall polymers isolated from pear cultivars with different textural attributes were 
Fig. 2 Cytochemical staining of cellulose in skin and cotyledon sections of raw and canned $\mathrm{HB}$ and SB beans using calcofluor white visualised using UV fluorescence. $\mathrm{Cu}$, cuticle; $\mathrm{ms}$, maclosclereid; os, osteosclereid; and $\mathrm{p}$, parenchyma. Scale bar $=$ $100 \mu \mathrm{m}$

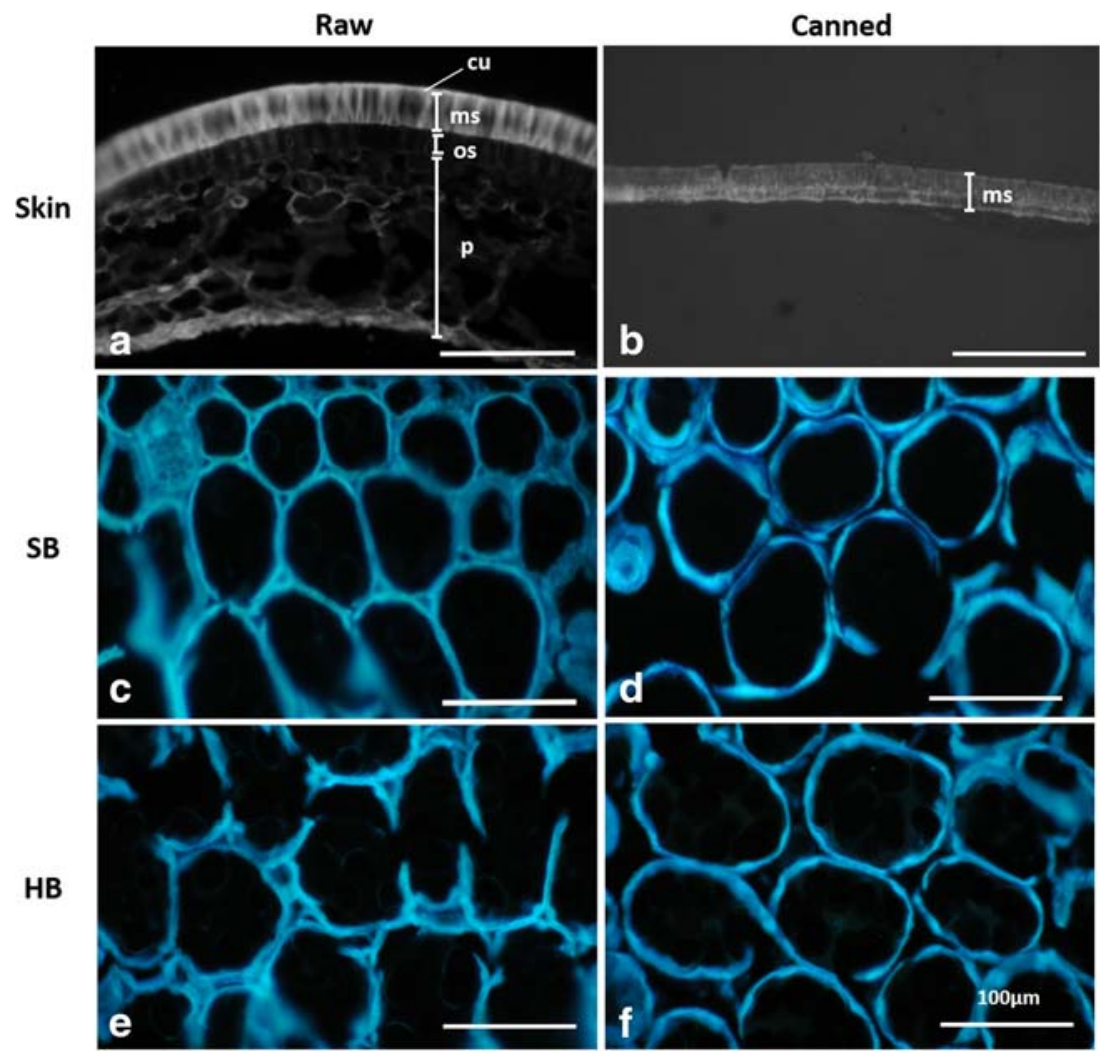

observed with atomic force microscopy (AFM). Watersoluble pectins from harder pears were more branched and prone to aggregation compared with those from soft texture cultivars. The authors conclude that branched water-soluble polymers could contribute to cell adhesion and tissue integrity. It is the first time that antibody techniques have been used to localise the cell wall polysaccharides in navy beans, giving a new insight of how cell wall components may influence tissue integrity and canning behaviour. Cell wall integrity and cell adhesion have important repercussions for the nutritional value of legumes. Intact cell walls may limit the hydration of starch during hydrothermal

\section{JIM5}
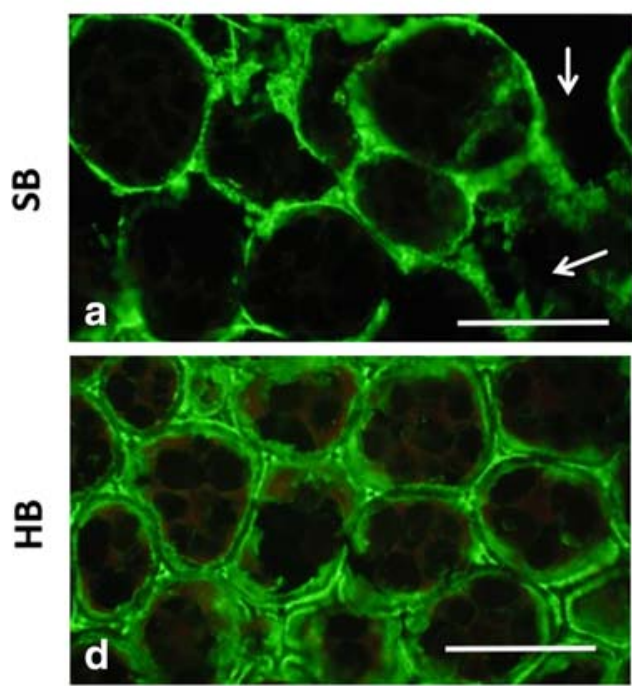

JIM7
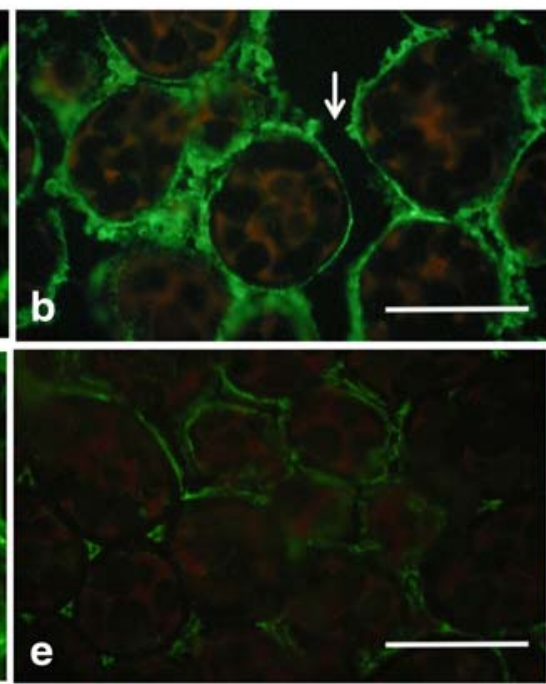

LM6
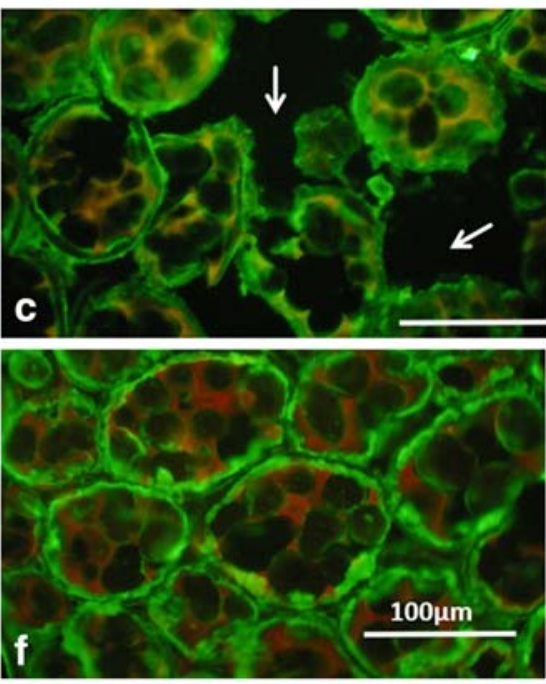

Fig. 3 Immunofluorescence labelling of pectic polysaccharide epitopes in cotyledon sections of canned HB and SB beans. Scale bar $=100 \mu \mathrm{m}$ 

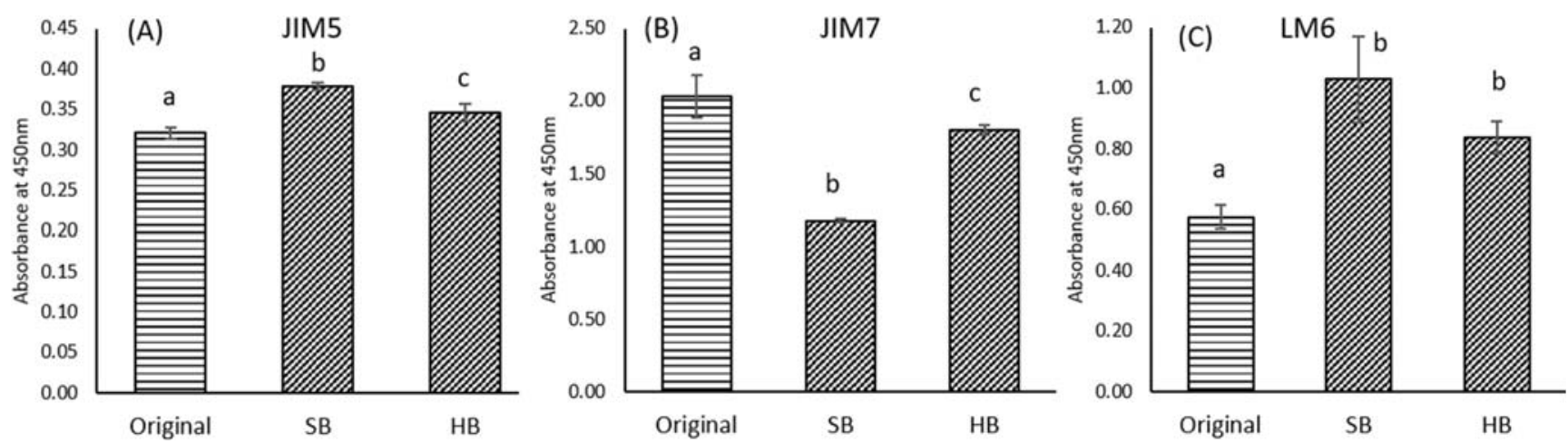

Fig. 4 Soluble pectin epitopes in canned sauce analysed by ELISA (absorbance at $450 \mathrm{~mm}$ ). Values show mean of 3 replicates with mean of standard error. Different superscript letters show significantly different results at $95 \%$ confidence level

processing and limit the accessibility of enzymes to starch and protein within the cells (Edwards et al. 2015). It would be interesting to investigate whether $\mathrm{HB}$ are less digestible and have a lower glycaemic index compared with SB.

\section{Solubility of Pectin Epitopes into the Canning Medium}

The same antibodies were used to analyse the canning medium (Fig. 4). These beans were canned in tomato sauce containing JIM5, JIM7 and LM6 epitopes. After canning, the abundance of JIM5 epitope in the canning medium increased significantly for both HB and SB (Fig. 4A), suggesting transfer of non-esterified $\mathrm{HG}$ from bean to canning medium. SB showed higher JIM5 epitope in the canning medium suggesting increased solubility of de-methyl-esterified HG. In contrast, the abundance of the JIM7 epitope decreased after canning in both types of beans, decreasing more in SB compared with HB. This could indicate beta-elimination of methylesterified HG in the sauce due to high temperature of canning process or de-methylation due to PME activity from the beans acting on the tomato pectin. Finally, the abundance of LM6 epitope increased significantly after canning compared with the original canning medium; the difference between HB and SB was not statistically significant. These results indicate an interplay between polymers in the canning medium and the beans and differences in HG solubility between $\mathrm{HB}$ and SB.

\section{Analysis of Cell Wall Polymers}

The yield of total dietary fibre was significantly higher in HB compared with SB (Table 1). Overall, both types of beans contained primarily water-insoluble polysaccharides ( $85 \%$ for SB and $90 \%$ for $\mathrm{HB}$ ), which are similar to other studies around 81-90\% (Ruiz-Ruiz et al. 2012; Yousif et al. 2007). However the proportion of water-soluble polymers was slightly but significantly reduced in HB compared with SB. The cell wall polymers were hydrolysed in $0.1 \mathrm{M}$ TFA which releases heat-labile neutral sugars. Analysis of the hydrolysates by HPAEC-PAD showed that the content of arabinose and galactose was higher in HB compared with SB and that arabinose and galactose containing polymers were significantly more soluble in SB. These results confirm the increased detection of the LM6 epitope in the canning medium. This result was comparable with the results found by Shiga et al. (2004) who suggested that the hardening of the beans involves insoluble neutral, arabinose-rich polysaccharides. Shiga et al. (2004) also suggested that Ara and $\mathrm{Gal}$ residues in pectin were usually found esterified to ferulic acid which is involved in polymer cross-linking. The hydrolysis protocol did not allow analysis of ferulic or uronic acids in the current study. The results of the present study confirm that solubilisation of branched RGI is associated with a softer bean phenotype.
Table 1 Yield of total dietary fibre (TDF) of canned $\mathrm{HB}$ and $\mathrm{SB}$ navy beans (\% wet weight basis), percentage solubility of polymers, and arabinose and galactose composition of $0.1 \mathrm{M}$ TFA hydrolysates with respective water solubility

\begin{tabular}{lllllll}
\hline & TDF & $\begin{array}{l}\text { TDF } \\
\text { soluble } \%\end{array}$ & Arabinose & $\begin{array}{l}\text { Arabinose } \\
\text { soluble } \%\end{array}$ & Galactose & $\begin{array}{l}\text { Galactose } \\
\text { soluble } \%\end{array}$ \\
\hline SB & $10.7 \pm 0.01^{\mathrm{a}}$ & $14 \%$ & $0.255 \pm 0.00^{\mathrm{a}}$ & $37 \%$ & $0.071 \pm 0.00^{\mathrm{a}}$ & $23 \%$ \\
$\mathrm{HB}$ & $16.4 \pm 0.01^{\mathrm{b}}$ & $10 \%$ & $0.365 \pm 0.00^{\mathrm{b}}$ & $18 \%$ & $0.126 \pm 0.00^{\mathrm{b}}$ & $10 \%$ \\
\hline
\end{tabular}

Values show mean of 3 replicates with standard deviation. $T D F$ total dietary fibre

Different letters within each column indicate statistically significant differences at $95 \%$ confidence level 


\section{Conclusion}

Navy beans are a global legume crop that require energyintensive hydrothermal processing to achieve optimal consumer acceptability. With climate change becoming a pressing global issue, understanding how climatic conditions affect crop, eating and nutritional quality will provide important information to breeders and processors. The observation that beans of the same cultivar but grown in different climates have different textural attributes offers an opportunity to study the cellular characteristics associated with the HTC phenomenon and may allow for selection of cultivars with particular processing and nutritional properties. This paper highlights the important role of plant cell walls and cell wall polymers in influencing the beans' mechanical and textural properties following hydrothermal processing.

Acknowledgements Our special thanks to Professor Paul Knox (Centre for Plant Sciences, University of Leeds) for providing us the antibodies used in this project. We also thank Heinz-Kraft for supplying commercial samples.

Funding Information This project was partially funded by Heinz-Kraft (Europe) through a PhD studentship to Jin Chu.

\section{Compliance with Ethical Standards}

Conflict of Interest The authors declare that they have no conflict of interest.

Open Access This article is licensed under a Creative Commons Attribution 4.0 International License, which permits use, sharing, adaptation, distribution and reproduction in any medium or format, as long as you give appropriate credit to the original author(s) and the source, provide a link to the Creative Commons licence, and indicate if changes were made. The images or other third party material in this article are included in the article's Creative Commons licence, unless indicated otherwise in a credit line to the material. If material is not included in the article's Creative Commons licence and your intended use is not permitted by statutory regulation or exceeds the permitted use, you will need to obtain permission directly from the copyright holder. To view a copy of this licence, visit http://creativecommons.org/licenses/by/4.0/.

\section{References}

Aldwairji, M. A., Chu, J., Burleyb, V. J., \& Orfila, C. (2014). Analysis of dietary fibre of boiled and canned legumes commonly consumed in the United Kingdom. Journal of Food Composition and Analysis, 36(1-2), 111-116.

Bernal-Lugo, I., Parra, C., Portilla, M., PenaValdivia, C. B., \& Moreno, E. (1997). Cotyledon thermal behavior and pectic solubility as related to cooking quality in common beans. Plant Foods for Human Nutrition, 50(2), 141-150.

Bourne, M. C. (2002). Food texture and viscosity : concept and measurement (2nd ed.). San Diego: Academic Press.

Brett, C., \& Waldron, K. (1996). Physiology and biochemistry of plant cell walls (2nd ed.). London: Chapman and Hall.
Caffall, K. H., \& Mohnen, D. (2009). The structure, function, and biosynthesis of plant cell wall pectic polysaccharides. Carbohydrate Research, 344(14), 1879-1900.

Challinor, A. J., Wheeler, T. R., Craufurd, P. Q., Ferro, C. A. T., \& Stephenson, D. B. (2007). Adaptation of crops to climate change through genotypic responses to mean and extreme temperatures. Agriculture, Ecosystems \& Environment, 119(1), 190-204.

Chu, J., Igbetar, B. D., \& Orfila, C. (2017). Fibrous cellular structures are found in a commercial fruit smoothie and remain intact during simulated digestion. Journal of Nutrition \& Food Sciences, 7(1).

Clausen, M. H., Willats, W. G. T., \& Knox, J. P. (2003). Synthetic methyl hexagalacturonate hapten inhibitors of antihomogalacturonan monoclonal antibodies LM7, JIM5 and JIM7. Carbohydrate Research, 338(17), 1797-1800.

Cuauhtémoc, R., Octavio, P., \& Elvira, G. (1993). Hard-to-cook phenomenon in common beans - a review. Critical Reviews in Food Science and Nutrition, 33(3), 227-286.

Cunniff, P., \& Horwitz, W. (2000). Official Methods of Analysis of the AOAC International, volume 2, Food Composition, Additives and Natural Contaminants (17th ed.). Arlington, VA: AOAC

Dourado, F., Barros, A., Mota, M., Coimbra, M. A., \& Gama, F. M. (2004). Anatomy and cell wall polysaccharides of almond (Prunus dulcis D. A. Webb) seeds. Journal of Agricultural and Food Chemistry, 52(5), 1364-1370.

Edwards, C. H., Warren, F. J., Campbell, G. M., Gaisford, S., Royall, P. G., Butterworth, P. J., \& Ellis, P. R. (2015). A study of starch gelatinisation behaviour in hydrothermally-processed plant food tissues and implications for in vitro digestibility. Food \& Function, 6(12), 3634-3641.

Erkinbaev, C., Derksen, K., \& Paliwal, J. (2017). Assessment of mung bean quality through single kernel characterization. Food and Bioprocess Technology, 10(12), 2156-2164.

Gooneratne, J., Majsaknewman, G., Robertson, J. A., \& Selvendran, R. R. (1994). Investigation of factors that affect the solubility of dietary fiber, as nonstarch polysaccharides, in seed tissues of mung bean (Vigna-Radiata) and black gram (Vigna-Mungo). Journal of Agricultural and Food Chemistry, 42(3), 605-611.

Henderson, L., Gregory, Y., \& Swan, G. (2002). Adults aged 19 to 64 years, types of quantities of foods consumed. National Diet and Nutrition Survey, 4, London: TSO.

Hentges, D. L., Weaver, C. M., \& Nielsen, S. S. (1991). Changes of selected physical and chemical components in the development of the hard-to-cook bean defect. Journal of Food Science, 56(2), 436442.

Hohlberg, A. I., \& Stanley, D. W. (1987). Hard-to-cook defect in black beans. Protein and starch considerations. Journal of Agricultural and Food Chemistry, 35(4), 571-576.

Ilker, R., \& Szczesniak, A. S. (1990). Structural and chemical bases for texture of plant foodstuffs. Journal of Texture Studies, 21(1), 1-36.

Jarvis, M. C., Briggs, S. P. H., \& Knox, J. P. (2003). Intercellular adhesion and cell separation in plants. Plant Cell and Environment, 26(7), 977-989.

Knox, J. P. (1997). The use of antibodies to study the architecture and developmental regulation of plant cell walls. International Review of Cytology - a Survey of Cell Biology, 171, 79-120.

Liu, K. (1995). Cellular, biological, and physicochemical basis for the hard-to-cook defect in legume seeds. Critical Reviews in Food Science and Nutrition, 35(4), 263-298.

Lu, W., \& Chang, K. C. (1996). Correlations between chemical composition and canning quality attributes of navy bean (Phaseolus vulgaris L). Cereal Chemistry, 73(6), 785-787.

Mafuleka, M. M., Ott, D. B., Hosfiled, G. L., \& Uebersax, M. A. (1991). Dry bean (phaseolus vulgaris) hardening and the consequences of pectin methylesterase activity in storage. Journal of Food Processing and Preservation, 15(1), 1-18. 
Manfield, I. W., Bernal, A. J., Moller, I., McCartney, I., Riess, N. P., Knox, J. P., \& Willats, W. G. T. (2005). Re-engineering of the PAM1 phage display monoclonal antibody to produce a soluble, versatile anti-homogalacturonan scFv. Plant Science, 169(6), 1090-1095.

McCartney, L., \& Knox, J. P. (2002). Regulation of pectic polysaccharide domains in relation to cell development and cell properties in the pea testa. Journal of Experimental Botany, 53(369), 707-713.

McCartney, L., Ormerod, A. P., Gidley, M. J., \& Knox, J. P. (2000). Temporal and spatial regulation of pectic (1 -> 4)-beta-D-galactan in cell walls of developing pea cotyledons: implications for mechanical properties. Plant Journal, 22(2), 105-113.

Mendoza, F. A., Cichy, K., Lu, R. F., \& Kelly, J. D. (2014). Evaluation of canning quality traits in black beans (Phaseolus vulgaris L.) by visible/near-infrared spectroscopy. Food and Bioprocess Technology, 7(9), 2666-2678.

Mohnen, D. (2008). Pectin structure and biosynthesis. Current Opinion in Plant Biology, 11(3), 266-277.

Ordaz-Ortiz, J. J., Marcus, S. E., \& Knox, J. P. (2009). Cell wall microstructure analysis implicates hemicellulose polysaccharides in cell adhesion in tomato fruit pericarp parenchyma. Molecular Plant, 2(5), 910-921.

Orfila, C. (2001) Structure and function of the plant cell wall in relation to cell adhesion in ripening tomato fruit. $\mathrm{PhD}$ University of Leeds.

Orfila, C., \& Knox, J. P. (2000). Spatial regulation of pectic polysaccharides in relation to pit fields in cell walls of tomato fruit pericarp. Plant Physiology, 122(3), 775-781.

Orfila, C., Seymour, G. B., Willats, W. G., Huxham, I. M., Jarvis, M. C., Dover, C. J., Thompson, A. J., \& Knox, J. P. (2001). Altered middle lamella homogalacturonan and disrupted deposition of (1->5)-alpha-L-arabinan in the pericarp of $\mathrm{Cnr}$, a ripening mutant of tomato. Plant Physiology, 126(1), 210-221

Pirhayati, M., Soltanizadeh, N., \& Kadivar, M. (2011). Chemical and microstructural evaluation of 'hard-to-cook' phenomenon in legumes (pinto bean and small-type lentil). International Journal of Food Science \& Technology, 46(9), 1884-1890.

Renard, C. M. G. C., \& Jarvis, M. C. (1999). A cross-polarization, magicangle-spinning,13c-nuclear-magnetic-resonance study of polysaccharides in sugar beet cell walls. Plant Physiology, 119(4), 13151322.

Rocca-Poliméni, R., \& Flick, D. (2019). Experimental and numerical study of the evolution of carrot texture during cooking in a pressure cooker. Food and Bioprocess Technology, 12(8), 1284-1292.

Rocha, S. M., Coimbra, M. A., \& Delgadillo, I. (2000). Demonstration of pectic polysaccharides in cork cell wall from Quercus suber L. Journal of Agricultural and Food Chemistry, 48(6), 2003-2007.

Ruiz-Ruiz, J. C., Davila-Ortiz, G., Chel-Guerrero, L. A., \& BetancurAncona, D. A. (2012). Wet fractionation of hard-to-cook bean (Phaseolus vulgaris L.) seeds and characterization of protein, starch and fibre fractions. Food and Bioprocess Technology, 5(5), 15311540 .
Sefa-Dedeh, S., Stanley, D. W., \& Voisey, P. W. (1979). Effect of storage time and conditions on the hard-to-cook defect in cowpeas (Vigna unguiculata). Journal of Food Science, 44(3), 790-795.

Shiga, T. M., Lajolo, F. M., \& Filisetti, T. M. C. C. (2004). Changes in the cell wall polysaccharides during storage and hardening of beans. Food Chemistry, 84(1), 53-64.

Shomer, I., Paster, N., Lindner, P., \& Vasiliver, R. (1990). The role of cellwall structure in the hard-to-cook phenomenon in beans (PhaseolusVulgaris L). Food Structure, 9(2), 139-149.

Stolle-Smits, T., Donkers, J., van Dijk, C., Derksen, J., \& Sassen, M. M. A. (1998). An electron microscopy study on the texture of fresh, blanched and sterilized green bean pods (Phaseolus vulgaris L.). Food Science and Technology-Lebensmittel-Wissenschaft \& Technologie, 31(3), 237-244.

Stolle-Smits, T., Beekhuizen, J. G., Kok, M. T., Pijnenburg, M., Recourt, K., Derksen, J., \& Voragen, A. G. (1999). Changes in cell wall polysaccharides of green bean pods during development. Plant Physiology, 121(2), 363-372.

Stolle-Smits, T., Beekhuizen, J. G., Recourt, K., Voragen, A. G. J. \& van Dijk, C. (2000) Preheating effects on the textural strength of canned green beans. 1. Cell wall chemistry. Journal of Agricultural and Food Chemistry, 48(11), 5269-5277.

Wang, C. C. R., \& Chang, S. K. C. (1988). Effect of selected canning methods on trypsin-inhibitor activity, sterilization value, and firmness of canned navy beans. Journal of Agricultural and Food Chemistry, 36(5), 1015-1018.

Willats, W. G., Limberg, G., Buchholt, H. C., van Alebeek, G. J., Benen, J., Christensen, T. M. I. E., Visser, J., Voragen, A., Mikkelsen, J. D., \& Knox, J. P. (2000). Analysis of pectin structure part 2 - analysis of pectic epitopes recognised by hybridoma and phage display monoclonal antibodies using defined oligosaccharides, polysaccharides, and enzymatic degradation. Carbohydrate Research, 327(3), 309320.

Willats, W. G., Orfila, C., Limberg, G., Buchholt, H. C., van Alebeek, G. J., Voragen, A. G., Marcus, S. E., Christensen, T. M., Mikkelsen, J. D., Murray, B. S., \& Knox, J. P. (2001). Modulation of the degree and pattern of methyl-esterification of pectic homogalacturonan in plant cell walls. Implications for pectin methyl esterase action, matrix properties, and cell adhesion. Journal of Biological Chemistry, 276(22), 19404-19413.

Yousif, A. M., Kato, J., \& Deeth, H. C. (2007). Effect of storage on the biochemical structure and processing quality of adzuki bean (Vigna angularis). Food Reviews International, 23(1), 1-33.

Zdunek, A., Koziol, A., Pieczywek, P. M., \& Cybulska, J. (2014). Evaluation of the nanostructure of pectin, hemicellulose and cellulose in the cell walls of pears of different texture and firmness. Food and Bioprocess Technology, 7(12), 3525-3535.

Publisher's Note Springer Nature remains neutral with regard to jurisdictional claims in published maps and institutional affiliations. 